\title{
CHEMICAL CONTROL OF PEACHES FROM CLASTEROSPORIOSIS IN THE CONDITIONS OF THE REPUBLIC OF UZBEKISTAN
}

\author{
Boyjigitov Fozil Mukhammadievich \\ Candidate of Agricultural Sciences, Senior Researcher, Scientific-Research Institute of Horticulture, \\ Viticulture and Winemaking named after Academician Makhmud Mirzaev, Tashkent district, Tashkent \\ Province, Uzbekistan
}

Article DOI: https://doi.org/10.36713/epra9197

DOI No: 10.36713/epra9197

\begin{abstract}
Peach varieties Istikbol and Gulnoz were found to be resistant to clasterosporiosis. The incidence rate ranged from 13.0 to $45.0 \%$, with the severity of the disease from 8.0 to $22.7 \%$. In the fight against clasterosporiosis, the chemical method is considered the most effective. For chemical protection, it is recommended early spring triple treatment of trees in the following terms: 1 - before the buds swell; 2 - after blooming of trees; 3 - two weeks after blooming, with one of the following fungicides: Skor 250 EC (normally 0.02\% suspension), Kresoxin 50\% WDG. (0.02\%), Topsin-M 70\% WP (0.1\%) and Falcon 46\% EC (0.05\%) against peach clasterosporiosis.
\end{abstract}

KEYWORDS: peach, fungus, disease, clasterosporiosis, fungicide, efficiency, productivity

\section{INTRODUCTION}

Horticulture is the most ancient branch of agriculture in Uzbekistan. Peach orchards are grown in the republic on 23.4 thousand hectares. To obtain a high-quality and high yield, along with the cultivation of productive, high-yielding, disease-resistant varieties, it is necessary to control pests and diseases in a timely manner.

The solution of these problems dictates the need to develop scientifically based systems of measures aimed at controlling pests and pathogens of various plant diseases.

Diseases of stone fruit crops affect the taste and appearance of fruits, reduce the shelf life and the yield. Ultimately, this leads to a sharp increase in the cost of production and negatively affects the profitability of farms. This determines the relevance of the problem we are studying.

The results of our study observations (2006-2008) show that in the conditions of Uzbekistan, the most common peach disease is clasterosporiosis.

Clasterosporiosis (kleasterosporiosis) disease is a very harmful disease of stone fruit crops in Uzbekistan. It causes especially the heaviest damage to apricots and peaches; during infestation, their leaves fall prematurely, shoots and branches wither and die, the fruits lose their commercial qualities, ripen poorly, lose stability to the penetration of the pathogen of moniliosis and other pathogens.

The causative agent of the disease is the fungus Clasterosporium carpophilum (Lev.) Aderh. belongs to the class Deuteromycetes, the order Hyphomycetales. The disease affects foliage, fruits, shoots, buds and flowers. Round spots appear on the leaves. The spots are in the form of pricks at first, later they grow up to 3$6 \mathrm{~mm}$ in diameter, become round with light brown to reddish brown borders.

The infected tissue quickly dies off and the leaf falls off, forming a hole, in connection with which the disease is called "perforated spotting" (holey spotting). The optimal temperature for germination of conidia is $18-22{ }^{\circ} \mathrm{C}$ and relative humidity of $70-80 \%$. The parasite hibernates in the form of mycelium, conidia and chlamydospores in the affected shoots, branches and buds $[2,3,6]$.

The causative agent of clasterosporiosis C. carpophilum was identified on a peach in 1848 by the French scientist Leveille. Later, this fungus was found in other countries, and not only on peaches, but also on trees of various stone fruit species [16].

C. carpophilum hibernates in wounds and gums on branches in the form of chlamydospores, conidia, and mycelium. Favorable conditions for the development of 


\section{SJIF Impact Factor 2021: 8.013| ISI I.F.Value:1.241| Journal DOI: 10.36713/epra2016 ISSN: 2455-7838(Online) EPRA International Journal of Research and Development (IJRD)

the disease are high humidity and a temperature of 18 $20{ }^{\circ} \mathrm{C}[11]$.

About the influence of the temperature factor on the pathogen of perforated spotting (C. carpophilum) on plums in the Pavlodar Irtysh region. Favorable temperature for the growth of mycelium $\left(20{ }^{\circ} \mathrm{C}\right)$ and sporulation of the fungus $\left(13-24{ }^{\circ} \mathrm{C}\right)$ has been established in the conditions of Pavlodar region. The incubation period of the disease on plum leaves varied from 2 to 5 days, depending on the air temperature [9].

Under laboratory conditions, the optimal temperature for mycelial growth of C. carpophilum was 20-30 ${ }^{\circ} \mathrm{C}$, the maximum germination of conidia was observed at $98.0-100 \%$ relative humidity [17].

Clasterosporiosis is one of the most common and harmful diseases of cherry in Krasnodar territory, which affects leaves, shoots, buds, flowers and fruits [7].

In the conditions of Moldova, one of the reasons for the premature wither of stone fruit crops is infestation of trees by clasterosporiosis [13]. The wide spread of the disease clasterosporiosis has been noted in Central Asia too [1].

In 1959, the incidence of stone fruit crops with clasterosporiosis in the south of Ukraine averaged $30.0 \%$. In some plantations, leaves and fruits of trees were affected by $60.0 \%$, and shoots - by $15.0 \%$. The infestation of peach and sweet cherry reached $87.0 \%$, cherry - up to $20.0 \%$ [4].

In the conditions of Armenia, the infestation by clasterosporiosis ranged from 88.0 to $100 \%$ on apricot, peach and plum trees. Clasterosporiosis in Dagestan affected peach leaves by $80.0-85.0 \%$, and apricot fruits from 45.0 to $80.0 \%$. In Moldova, the disease was found in all gardens in irrigated areas, especially in the Chimislia and Kalarash regions (from 40.0 to $85.0 \%$ ), as well as in the Tiraspol region (from 90.0 to $100 \%$ of affected cherry and sweet cherry leaves) [10].

In stone fruit orchards under irrigated conditions of the steppe zone of Ukraine, I.V. Pariy et al. [12] discovered the infestation of apricot with moniliosis and of a peach branches with clasterosporiosis. They revealed the dependence of the degree of disease damage on planting density and meteorological conditions.

Clasterosporiosis is a widespread disease of various stone fruits. The author notes that one of the most common consequences of clasterosporiosis is the formation of wounds on tree trunks. In this regard, he points out the choice of a favorable place for laying new gardens and the use of healthy planting material as promising measures. On the basis of the materials obtained in the study of the nature of clasterosporiosis, the biology of the fungus - the causative agent, the influence of environmental factors on the manifestation of the disease, researchers have developed some measures aimed at combating this disease [18].

According to I.G. Jafarov [5], apricot plants and fruits in Azerbaijan are mainly affected by fungal diseases. Clasterosporiosis affects all varieties grown in gardens. In the recommendations for horticultural farms in Azerbaijan, they note that copper-containing preparations should be used before and after flowering, and all other treatments should be performed with triazole pesticides (Bayleton, Topaz, Topsin-M and Saprol).

Analyzing the vast literary material of domestic and foreign researchers on the issue under study, we came to the conclusion that diseases such as clasterosporiosis are widespread, very harmful and cause enormous economic damage to fruit growing throughout the world.

In this regard, we set ourselves the task of identifying and determining the main diseases of stone fruit crops in various conditions of Uzbekistan, studying some issues of bioecology of causative agents of major diseases, establishing the varietal resistance of crops and the effectiveness of various norms and terms of application of new fungicides in the control of diseases.

\section{MATERIALS AND METHODS}

The intensity of the spread and severity of clasterosporiosis on trees was determined by examining 100 leaves and fruits taken from ten shoots from four sides of the crown of tree according to the method of V.V. Kosov, I. Ya. Polyakov [8] and K.M. Stepanov, A.Ye. Chumakov [15].

Testing experiments on chemical preparations against peach clasterosporiosis disease. Each version had 3 trees.

When testing fungicides in each of the three replications of the experiment, 3 shoots were taken, of which the average ones were taken into account. The first treatment was carried out in the swelling of the buds, the second - after blooming, the third - two weeks after blooming of trees. The consumption rate of the testing liquid in the gardens, depending on the age of the plants, was 10001 / ha.

The percentage of plant damage was calculated using the formula:

$$
P=\frac{a \times 100}{n}
$$

where, $\mathrm{P}$ - number of infected plants, \%;

$\mathrm{a}$ - number of infected plants, pieces; $\mathrm{n}$ - total number of plants under testing.

The percentage of disease severity was determined by the following formula:

$$
P=\frac{\left.\sum a \times b\right) \times 100}{N \times K} ;
$$

where, $P$ - percentage of disease severity, \%; $\sum(a \times b)$ - the sum of the multiplication of the number of infected plants $(a)$ by the corresponding damage $(b)$ 


\section{SJIF Impact Factor 2021: 8.013| ISI I.F.Value:1.241| Journal DOI: 10.36713/epra2016 ISSN: 2455-7838(Online) EPRA International Journal of Research and Development (IJRD)

score; $N$ - total number of recorded plants; $K$ - high score for infestation rate.

The biological effectiveness of preparations was calculated according to the indicator of the severity of the disease:

$$
B e f=\frac{P k-P o}{P k} \times 100
$$

where, $B_{\text {ef }}$ - biological effectiveness, $\% ; P_{k}$ disease severity, control variant, $\% ; P_{o}$ - disease severity, testing variants, $\%$.

\section{RESULTS AND DISCUSSION}

In the complex of measures that ensure durability, high stable yields and the expansion of the areas of stone fruit plantations, a prominent place is occupied by the fight against their diseases. As we know, many diseases of stone fruit trees are caused by fungi, and of biotic factors, they cause the greatest damage to fruit trees. Moreover, some fungal diseases are so widespread that they take on the character of epiphytoties and cause large crop losses. Others of them develop slowly - chronically and have a long-term negative effect on the durability of the tree, yield and quality of fruits [14].

Surveys (2006-2008) in the orchards of various zones of Uzbekistan have shown, as noted, that one of the most common diseases of peaches is clasterosporiosis.

Clasterosporiosis disease, caused by the fungus C. carpophilum, is found in almost all areas of the world, affecting various types of stone fruit crops. In the conditions of Uzbekistan, peach clasterosporiosis is widespread and causes the heaviest damage to fruit growing.

The susceptibility of peach to clasterosporiosis was studied in four zones of our republic. According to the research results, less susceptibility was noted on the Istikbol variety in the gardens of the Research Institute of Plant Growing. In 2007, the susceptibility to clasterosporiosis was noted to be $31.0 \%$ on leaves, $20.0 \%$ on shoots, and $34.0 \%$ on fruits, with the development of the disease from 10.7 to $15.4 \%$.

In 2006 and 2008, the susceptibility of this variety was on leaves from 20.0 to $28.0 \%$, on shoots from 10.0 to $13.0 \%$ and on fruits from 23.0 to $30.0 \%$, with the development of the disease up to $14.0 \%$.

In the zones of Samarkand, Kashkadarya and Fergana regions, the peach varieties Gulnoz, Elberta and Champion were affected by clasterosporiosis in an average degree. In 2006-2008, infestation ranged on leaves from 27.0 to $46.0 \%$, shoots from 17.0 to $33.0 \%$ and fruits from 30.0 to $49.0 \%$, with the development of the disease from 9.0 to $23.5 \%$.

Lola variety was found to be susceptible to clasterosporiosis. In 2006-2008, susceptibility ranged on leaves from 43.0 to $69.0 \%$, shoots from 30.0 to $57.0 \%$ and fruits from 47.0 to $73.0 \%$, with the disease severity from 16.0 to $36.0 \%$.

In recent years, new varieties of stone fruit crops have been developed and introduced into production in the Republic of Uzbekistan. However, they have not been specifically tested for resistance to various diseases.

For three years (2006 - 2008), we have studied the clasterosporiosis disease of the most common varieties of peach in the collection nursery of the Research Institute of Plant Growing (Fig. 1).

Data of 2006-2007 showed susceptibility of the peach varieties Elbert, Lola and Start to clasterosporiosis disease. The spread rate of the disease on leaves ranged from 62.0 to $75.0 \%$, on shoots from 47.0 to $63.0 \%$, on fruits from 64.0 to $79.0 \%$, with the development of the disease from 19.0 to $36.4 \%$. In 2008, these varieties of peach were affected by clasterosporiosis to a moderate extent. Infestation on leaves ranged from 40.0 to $51.0 \%$, shoots - from 30.0 to $40.0 \%$, fruits - from 45.0 to $56.0 \%$. 


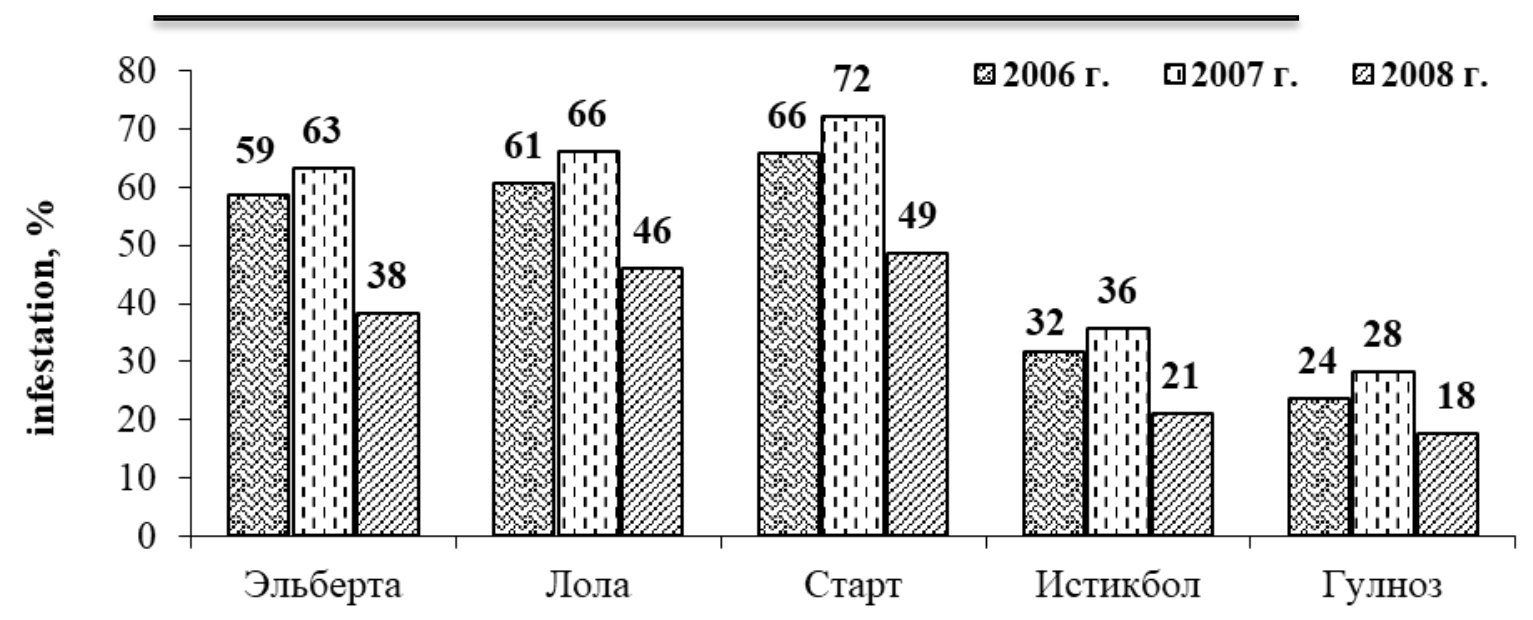

Figure 1. Infestation of peach varieties by clasterosporiosis

Peach varieties Istikbol and Gulnoz were found to be resistant to clasterosporiosis. In 2006-2007, their affection on leaves ranged from 28.0 to $42.0 \%$, shoots from 13.0 to $20.0 \%$, fruits - from 30.0 to $45.0 \%$, with the development of the disease from 8.0 to $22.7 \%$.

In 2008, the varieties Elberta and Gulnoz were infected to a lesser extent. The manifestation of symptoms of the disease on the leaves ranged from 20.0 to $24.0 \%$, on shoots - up to $10.0 \%$, on fruits from 23.0 to $29.0 \%$, with the development of the disease from 5.5 to $12.0 \%$.

Thus, our research can serve as a basis for recommending to take into account the resistance of varieties when expanding the plantings of these crops. In the complex of measures that ensure durability, high stable yields and the expansion of the areas of stone fruit plantations, a prominent place is occupied by the fight against their diseases.

Along with the breeding of resistant varieties to a complex of diseases of stone fruit crops, the chemical method of control is of great importance in preventing plant diseases and preserving the harvest. It is also valuable as a radical solution to the problem. In this regard, the study and evaluation of highly effective and less harmful fungicides to the warm-blooded are a very promising direction in plant protection.

In the control of diseases of stone fruit crops, good results were obtained with a single spraying with fungicides before swelling of the buds and two treatments after flowering.

Clasterosporiosis of stone fruits, as noted, is widespread throughout the world and affects fruits, leaves, and branches on which characteristic tubercles are formed. The appearance of the fungus C.carpophilum is always accompanied by the release of gum. In the fight against clasterosporiosis, the chemical method is considered the most effective.

The first spraying of plants is carried out at the beginning of the flowering phase, the second - after flowering, the third - after another two weeks. The most effective systems were the application of chorus $(0.35$ $\mathrm{kg} / \mathrm{ha}$, once) and topaz (0.4 1/ ha, twice) - 94.6\%; chorus $(0.351 /$ ha, once $)$ and vectra $(0.31 /$ ha, twice $)$ $87.0 \%$ [7]. 


\section{EPRA International Journal of Research and Development (IJRD)}

Volume: 6 | Issue: 12 | December 2021

Table

Biological efficiency of fungicides in the control of peach clasterosporiosis. Samarkand Scientific Experimental Station under SRIHVW named after academician M. Mirzaev

(in 2017 year)

\begin{tabular}{|c|c|c|c|c|c|c|c|}
\hline № & $\begin{array}{l}\text { Preparations and active } \\
\text { ingredients }\end{array}$ & 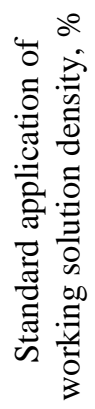 & 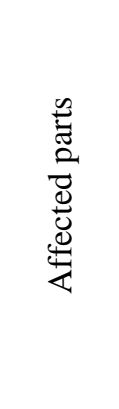 & 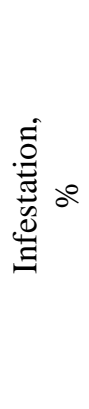 & 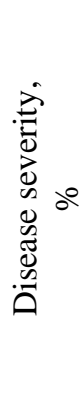 & 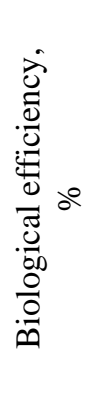 & 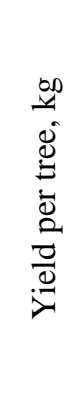 \\
\hline \multirow[t]{3}{*}{1.} & \multirow{3}{*}{ Control } & \multirow{3}{*}{ - } & leaves & 30,0 & 15,5 & - & \multirow{3}{*}{7,0} \\
\hline & & & shoots & 20,0 & 11,0 & - & \\
\hline & & & Fruits & 33,0 & 13,4 & - & \\
\hline \multirow[t]{3}{*}{2.} & \multirow{3}{*}{$\begin{array}{c}\text { Bayleton, } \\
25 \% \text { WP } \\
\text { (triadimefon) (standard) }\end{array}$} & \multirow{3}{*}{0,02} & Leaves & 16,0 & 6,2 & 60,0 & \multirow{3}{*}{15,0} \\
\hline & & & shoots & 13,0 & 4,3 & 61,0 & \\
\hline & & & Fruits & 14,0 & 4,8 & 64,0 & \\
\hline \multirow[t]{3}{*}{3.} & \multirow{3}{*}{$\begin{array}{c}\text { Skor } \\
250 \text { EC }(250 \mathrm{~g} / \mathrm{l}) \\
\text { (difenoconazole) }\end{array}$} & \multirow{3}{*}{0,02} & Leaves & 9,0 & 1,6 & 89,6 & \multirow{3}{*}{17,5} \\
\hline & & & shoots & 7,0 & 1,2 & 89,0 & \\
\hline & & & Fruits & 6,0 & 1,3 & 90,0 & \\
\hline \multirow[t]{3}{*}{4.} & \multirow{3}{*}{$\begin{array}{c}\text { Kresoxin } \\
50 \% \text { WDG } \\
(\text { kresoxim-methyl) }\end{array}$} & \multirow{3}{*}{0,02} & Leaves & 10,0 & 2,0 & 87,0 & \multirow{3}{*}{15,2} \\
\hline & & & shoots & 7,0 & 1,2 & 89,0 & \\
\hline & & & Fruits & 8,0 & 1,6 & 88,0 & \\
\hline \multirow[t]{3}{*}{5.} & \multirow{3}{*}{$\begin{array}{c}\text { Topsin-M } \\
70 \% \mathrm{WP} \\
\text { (thiophanate methyl) }\end{array}$} & \multirow{3}{*}{0,1} & Leaves & 9,0 & 1,5 & 90,3 & \multirow{3}{*}{16,8} \\
\hline & & & shoots & 7,0 & 1,0 & 91,0 & \\
\hline & & & Fruits & 8,0 & 1,2 & 91,0 & \\
\hline \multirow[t]{3}{*}{6.} & \multirow{3}{*}{$\begin{array}{c}\text { Falcon } \\
46 \% \mathrm{EC} \\
\text { (tebuconazole }+ \\
\text { spiroxamine }+ \\
\text { triadimenol) }\end{array}$} & \multirow{3}{*}{0,05} & Leaves & 13,0 & 2,4 & 84,5 & \multirow{3}{*}{16,0} \\
\hline & & & shoots & 7,0 & 1,6 & 85,5 & \\
\hline & & & Fruits & 10,0 & 2,0 & 85,0 & \\
\hline
\end{tabular}

It is well known that the degree of influence of chemicals on diseases is ambiguous and depends on the soil and climatic conditions, the agricultural technology used, the terms of application and the rate of consumption of the preparations. To develop an effective chemical control method, experiments were carried out to test new fungicides against peach clasterosporiosis disease.

In 2017, production tests of preparations Skor 250 EC normally $0.02 \%$ suspension, Kresoxin 50\% WDG. normally $0.02 \%$, Topsin-M $70 \%$ WP normally $0.1 \%$ and Falcon $46 \%$ EC. normally $0.05 \%$ were carried out. As a result of this, the best results were obtained against peach clastersporiosis. Bayleton of $0.02 \%$ was used as standard variant.

In 2008, the observations carried out on the susceptibility of peach to clasterosporiosis in the gardens of the Samarkand Scientific Experimental Station under SRIHVW named after academician $M$.
Mirzaev showed the following: in the control variant, the disease developed strongly, infestation on leaves reached $30.0 \%$, on shoots $-20.0 \%$ and fruits $-33.0 \%$, with the development of the disease 15.5, 11.0 and $13.4 \%$, respectively. Up to $7 \mathrm{~kg}$ of poor-quality and non-standard harvest was obtained from one tree (table).

Preparations Skor 250 EC (normally 0.02\% suspension), Kresoxin 50\% WDG. (0.02\%), Topsin-M $70 \%$ WP $(0.1 \%)$ and Falcon $46 \%$ EC $(0.05 \%)$ showed good results in the fight against clasterosporiosis. Biological efficiency on leaves was from 84.5 to $90.3 \%$, on shoots from 85.5 to $91.0 \%$ and fruits - from 85.0 to $91.07 \%$. The yield per tree was $15.2-17.5 \mathrm{~kg}$.

In the standard variant, where $0.02 \%$ Bayleton was used, the biological efficiency was $60.0 \%$ on leaves, $61.0 \%$ on shoots, $64.0 \%$ on fruits with the development of the disease $6.2,4.3$ and $4.8 \%$, respectively. 


\section{SJIF Impact Factor 2021: 8.013| ISI I.F.Value:1.241| Journal DOI: 10.36713/epra2016 ISSN: 2455-7838(Online) EPRA International Journal of Research and Development (IJRD)

\author{
Volume: 6 | Issue: 12 | December 2021
} \\ - Peer Reviewed Journal}

\section{CONCLUSION}

For chemical protection, it is recommended three times early spring treatment of trees in the following terms: 1 - before the buds swell; 2 - after blooming of trees; 3 - two weeks after blooming, with one of the following fungicides: Skor 250 EC (normally $0.02 \%$ suspension), Kresoxin 50\% WDG $(0.02 \%)$, Topsin-M $70 \%$ WP $(0.1 \%)$ and Falcon $46 \%$ EC $(0.05 \%)$ against peach clasterosporiosis

\section{REFERENCES}

1. Aslanov D.B. Spotting (clasterosporiosis) of stone fruit crops and a way to combat it. / Bulletin of the Academy of Sciences of Turkmenistan. - Ashgabat, 1955a. - P.41.

2. Golovin P.N., Arsenyeva M.V., Khaleeva Z.N., Shestiperova Z.I. Plant pathology. - L: Kolos, 1980. Pp. 289-292.

3. Dementyeva M.N. Diseases of fruit crops. - Moscow, 1962 .-P. 50.

4. Dementyeva M.I. Clasterosporiosis disease. Plant pathology. - Moscow, 1970 .-P. 374.

5. Jafarov I.G. Diseases of apricot fruits // J. Plant protection and quarantine. - Moscow, 2002. - No. 6. P.35.

6. Idrisov S. Clasterosporiosis of stone fruit // J. Protection and quarantine of plants. - Moscow, 1977. No. 7. - P.37.

7. Kim A.V. Against cherry clasterosporiosis // J. Plant protection and quarantine. - Moscow, 2004. - No. 1. P.28.

8. Kosova V.V., Polyakova I.Ya. Prediction of the appearance and registration of pests and diseases of agricultural crops. - M., 1958. - Pp.504-511

9. Kosogorova E.A. Influence of the temperature factor on the causative agent of perforated spotting of stone fruit and its manifestation. // Scientific. tr. Novosib. agricultural institute. - Novosibirsk, 1979. - Pp. 50-54.

10. Naumova I.P., Shekochihina R.I. Clasterosporiosis / Proceedings of ARRIPP, Ed. 22. - L., 1964. - P.34.

11. Ovcharenko G.V. On the biology of the causative agent of clasterosporiosis in stone fruit varieties in the Crimea // Proceedings of the Nikitsky Botanical Garden. T. XXXIX. 1967. - Pp. 423-433.

12. Pariy I.O., Barabash N.A. Fungal diseases in stone fruit plantations // J. Horticulture and viticulture. Moscow, 1988. - No. 6. - Pp. 15-17.

13. Paterilo G.A. Clasterosporiosis // J. Horticulture, viticulture and winemaking in Moldova. - Kishenev, 1957. - No. 6. - P.32.

14. Popushoi I.S. Diseases of desiccation of stone fruit trees in Russia. - Kishenev: Academy of Sciences of Moldova, 1970. - Pp. 99-102.

15. Stepanova K.M., Chumakova A.E. Forecast of diseases of agricultural plants. - L..: "Kolos", 1972. - P.271.

16. Aderhold R. Arbeiten der botanischen Abteilung der versuchsstasien des kol. pomologisch. Bd. 1901. No. 7. - p.16.

17. Ernest Lawrence G., Eldon Zehr. Influence of environmental factors on the development and spread of C. carpophilum on peach. Phytophatology. 1982. No. 7. - Pp.773-776.

18. Molnar Jozef Zahradnictvo. Clasterosporiosis disease of stone fruit - 1989. - No. 6. - Pp.251-253.
19. Allayarov A., Abdurakhmanova S., Khakimov A. The spread of alternaria leaf spot disease in cabbage vegetable plants, its damages and the efficacy of fungicides used against them. EPRA International Journal of Research and Development (IJRD), 2019, February, Volume 4, Issue 2, P.118-122.

20. Allayarov A, Zuparov M., Khakimov A., Omonlikov A. Application of the biopreparation 'Orgamika $F$ ' against fusarium disease of cabbage and other cole vegetables. E3S Web Conf., Volume 284, 2021. Topical Problems of Green Architecture, Civil and Environmental Engineering (TPACEE-2021), Article Number-03011. DOI:10.1051/e3sconf/202128403011

21. Boijigitov, F., \& Khakimov, A. (2018). Some bioecological features of pathogens shot-hole disease and brown fruit rot. Bulletin of Science and Practice, 4(12), 268-272. http://doi.org/10.5281/zenodo.2257601

22. Mamiev M.S., Khakimov A.A., Zuparov M.A., Rakhmonov U.N. Effectiveness of different fungicides in controlling botrytis grey mould of tomato. $\quad 1 s t$ International Conference on Energetics, Civil and Agricultural Engineering 2020" (ICECAE 2020), 1416 October 2020, 614, 012112

23. Khakimov A.A., Omonlikov A.U. and Utaganov S.B. Current status and prospects of the use of biofungicides against plant diseases. GSC Biological and Pharmaceutical Sciences, 2020, 13(03). pp. 119-126. https://doi.org/10.30574/gscbps.2020.13.3.0403 